\title{
Performing Genre: Tragic Curtains, Tragic Walking and Tragic Speaking
}

\section{Tiffany Stern}

\section{(2) OpenEdition \\ 1 Journals}

\section{Electronic version}

URL: https://journals.openedition.org/shakespeare/5904

DOI: $10.4000 /$ shakespeare.5904

ISSN: 2271-6424

\section{Publisher}

Société Française Shakespeare

\section{Electronic reference}

Tiffany Stern, "Performing Genre: Tragic Curtains, Tragic Walking and Tragic Speaking", Actes des congrès de la Société française Shakespeare [Online], 39 | 2021, Online since 19 May 2021, connection on 23 August 2021. URL: http://journals.openedition.org/shakespeare/5904 ; DOI: https://doi.org/ $10.4000 /$ shakespeare.5904

\section{This text was automatically generated on 23 August 2021}

(c) SFS 


\title{
Performing Genre: Tragic Curtains, Tragic Walking and Tragic Speaking
}

\author{
Tiffany Stern
}

1 In his New World of English Words, Edward Phillips characterises a "Tragedian" as "a writer of [...] a sort of Dramatick Poetry [...] representing murthers, sad and mournfull actions." ${ }^{1}$ He may be picking up on Florio's New World of Words which had defined a "comedian" as, no surprise, a "writer of comedies." ${ }^{2}$ Both seem, now, self-evident as definitions. But Shakespeare, who was, according to these classifications, both a tragedian and a comedian, used those same words in a different sense. When Rosencrantz lets Hamlet know that "the Tragedians of the City" (Hamlet, TLN 1375) have arrived, or when Cleopatra worries that "The quicke Comedians / Extemporally will stage us" (Antony and Cleopatra, 1459-60) it is actors, not writers, who are being referred to. ${ }^{3}$ Moreover, in his lifetime Shakespeare himself was credited for being a "tragedian" and "comedian" when a player not a playwright: in the cast list appended to Ben Jonson's Every Man in His Humour (1598) he is one of the ten "principall Comoedians"; in the cast list for Jonson's Sejanus (1603) he is one of the eight "principall Tragoedians." ${ }^{4}$ While, then, in dictionary terms, tragedian and comedian were words to describe types of playwright, for Shakespeare, as for Jonson, they were words to describe types of actor. The suggestion is that, for Shakespeare, Jonson and other early modern playwrights, mode of performance was as much part of genre as mode of writing.

2 This article is on performing tragedy. It looks at three aspects of tragic stage production: tragic curtains; tragic walks; and speaking in a tragic tone. In exploring how tragedy could be conveyed materially and physically, beyond, beside or without words, it shows how crucial staging was to a play's categorisation and hence meaning. ${ }^{5}$

\section{Tragic Staging}

From the moment one entered it, the performance space itself might be visibly and obviously "tragic." Along the back of the early modern stage - the area that was also 
the front of the tiring house - were curtains, that could be selected, it seems, on a playby-play basis. Sometimes they were "tragic." Thus in "Visions of the worlds instabillitie" Rowlands relates seeing "A spatious Theatre" and realising it is "All hang'd with black to act some tragedie": "tragedy", in the form of black drapery, has preceded the start of the play. ${ }^{6}$ And, when the three genres Comedy, History and Tragedy struggle for mastery in the prelude to A Warning for Fair Women, "History", too, finally looks up and realises that the genre of the play is already predetermined: "The stage is hung with blacke: and I perceive / The Auditors preparde for Tragedie." Tragedy could happen in advance of text, then, in which case it was an aspect of mood, atmosphere and theatrical experience as well as a label for the words.

Curtains with tragic import are often written about within plays, but seldom make it to opening stage directions, because printed plays tend to start only when the words do. ${ }^{8}$ But when Bellamont in Northward Ho intends to have a tragedy performed he wants "the stage" to be "hung all with black velvet"; 9 when William Browne sees the world "clad in a mourning robe" he compares it to "A Stage made for a wofull Tragedie"; ${ }^{10}$ and when "Truth", in the induction to Two Lamentable Tragedies, relates how "Our Stage" is decorated, he says that it "doth weare the habiliments of woe": it is draped in funereal black. ${ }^{11}$

Occasionally, too, we can spot moments when tragic curtains are in use in plays. In John Marston's Insatiate Countess (perf. Whitefriars Theatre c. 1610), “The stage of heav'n, is hung with solemne black, / A time best fitting, to Act Tragedies", ${ }^{12}$ suggesting that a particular part of the stage (the "heavens" was the name for the canopy or the internal roof that covered the performance area) is shrouded in tragic drapery. But in Shakespeare's [?] 1 Henry VI (perf. Rose Playhouse, 1591?), located in "histories" in the folio (though with a title that does not mention genre at all), Bedford proclaims "Hung be $y^{\mathrm{e}}$ heavens with black" (TLN 9). The statement might be a reminder that the heavens are indeed hung with black, and that tragedy - as well as, in the case of the play, a fictional funeral - is there from the start; or might draw attention to the fact that the stage "heavens" are not, in fact, hung with black (but should be), and that the world is out of joint - or, rather, that the staging is denying genre. Both plays start by calling attention to genre through curtains, then, but in what way is not clear. We can never know when tragic curtains were used: just that their use was a possibility, and that it will subtly have altered the play's meaning.

For context, it is worth observing that other genres, too, could be conveyed through curtains. When "The Stage [is] all hang'd with the sad death of Kings, / From whose bewailing story sorrow springs", what seem to be projected are "history" curtains. ${ }^{13}$ Other narrative theatre curtains hint at "history" too, like the battle curtains, referred to by Jasper Mayne, who writes of "dead Arras-Captains, which in hangings threaten to assault the spectator with imaginary, woven Lunces." ${ }^{14}$ It is important to tread carefully here, however: these references may be to staged "fictional" rather than genre curtains, or may, too, refer to the theatre curtains that surrounded the audience rather than the stage. But the fact that the narrative on them is genre specific, and of practical use (battle curtains can swell army numbers on a sparse stage), suggests that history, too, was sometimes relegated to hangings. The result, if so, will have been that a living king could be portrayed in front of "king's death" curtains; or a peaceful meeting, or a warlike one, enacted in front of "battle" curtains. If such curtains were an aspect of 
genre, too, they would, like tragedy ones, also change in meaning as the play progressed: they would predict, then add to, and then memorialise a moment of story.

There may, too, have been "comedy" curtains - though, again, information about them is hard to quantify. When a boy speaker in the Induction to Jonson's Cynthia's Revels draws a distinction between himself and a particular kind of theatre decoration, "I am none of your fresh pictures, that use to beautifie the decaied dead arras, in a publike theatre", comedy curtains - beautiful boy curtains - seem to be being projected..$^{15}$ Attractive curtains, Jonson also suggests, were an easy way of smartening up a wornout theatre arras (suggesting, presumably, that they were made of painted cloths that could be substituted for, or overlaid onto, more expensive tapestry).${ }^{16} \mathrm{~A}$ vignette on the playbook of Nathaniel Richards' Messalina (1640), consisting of a series of images drawn by fellow-playwright Thomas Rawlins, seems to show a stage with comedy curtains: on the right side there is a Cupid with a bow and arrow poised to shoot; on the left, a person about to be hit (see Fig. 1).

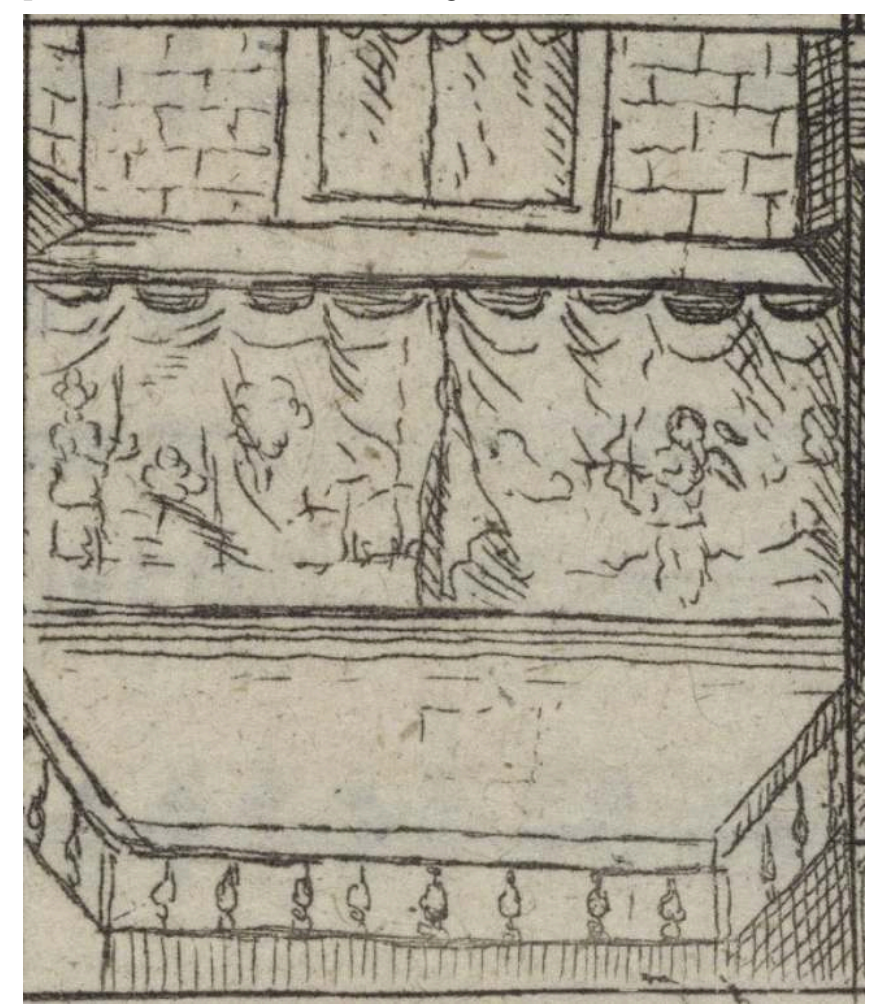

Fig. 1. Vignette from the title page of Nathaniel Richards' The Tragedy of Messallina the Roman Emperesse (1640) in the Folger Shakespeare Library.

Both Richards and Rawlins put on plays at Salisbury Court, and probably that stage is being depicted here. Yet, confusingly, these curtains are shown on the title page for a tragedy. Perhaps, then, they are "love" (or "lust") curtains, rather than strictly comic ones. In terms of Richard's Messalina, they may be drawing attention to the lust of "Romes mightie Whore" Messalina, ${ }^{17}$ or they may be intended specifically to illustrate the prologue for that play, who says to the audience, "Your loves the marke we ayme at, all our might, / Shootes at your love, labours to hit that white."18 They could, of course, be both Messalina-lust and Prologue-love curtains: if fixed throughout production, the "victim" of the curtains would change from the audience (in the prologue), to the wronged husband Claudius, and perhaps lastly to Messalina herself? These examples raise further questions about interpretation. Just as play titles read 
differently at the start and end of plays - Love's Labour's Lost; 'Tis Pity She's a Whore - so genre curtains, even if fixed, do not have only one meaning. They require reinterpretation throughout production.

All the instances cited so far raise questions about genre curtains more broadly, of course. How often were they used ironically, or at least in an ambiguous way - as with seemingly comic curtains to front a tragedy? And how often was genre, rather than fictional location, the focus of curtains at all? And then there is the biggest question of all: how permanent were genre curtains for the productions that used them - could they be changed during performance or were they a permanent statement about their particular drama?

None of these questions is easily answerable. Mariko Ichikawa provides examples of three plays that just possibly contain curtain-changes, but they are so ambiguous that, if anything, they suggest that removing and replacing hangings during performance was unusual - or didn't happen at all. ${ }^{19}$ The fact that many tragedies are set at night, and that they tend to lead to funerals, may suggest the reverse: that the curtains, if there at all, were there throughout. ${ }^{20}$

11 It is worth considering how the presence or absence of tragedy curtains might have inflected some of Shakespeare's famous dramas. Was Polonius in Hamlet, for instance, killed not only through an arras, but through "tragedy" (Hamlet TLN 2405), the curtains then predicting and mourning his death, and notionally already in place for his funeral? Likewise, when Hamlet wears black - in fictional terms because he is in mourning for his father; in metatheatrical terms, because he bears "tragedy" about his person - was he additionally performing in front of tragedy curtains? If so, then his tragic body will hardly have been visible: he will have been subsumed by his genre. The love of Claudius and Gertrude, on the other hand, will have been foregrounded - or, rather, backgrounded - by tragedy in curtain terms from the start. Conversely, if Hamlet's performance was located only in his own clothing, and not also in curtains, then the genre will have been focused on him: indeed, his own downfall and death may have been there from dress onwards. Or what of Othello? While a black tempura seems to have been used to darken faces on stage, black gloves and hose - black cloth - seem often to have been used to colour arms and legs: Othello's very body may have resembled the tragedy that would overtake him. ${ }^{21}$ And would his actual face have seemed to meld into his tragic background (actors of colour have recently called attention to the way dark stages put them at a visual disadvantage)? ${ }^{22}$ And what of those characters who wear black though they are in comedies? Olivia, also in mourning in Twelfth Night, and Mercade, entering Love's Labour's Lost to announce a death, are conveying "tragedy": will that have seemed a horrifying form of genre confusion on the "happy" stage? Or will genre have always been a character as well as a play option?

As so often, the problems in answering such questions have to do with theatre history itself: it provides what it provides and no more. It is frustrating not to know which plays used genre curtains, how long they hung on the stage, whether and when they were used straightforwardly or ironically. But using black cloth, misusing it, and placing it on characters, were, it seems, prompts for interpretation that could have been called upon and that sometimes were. The fact that productions had the option of foregrounding genre makes genre a key issue whether employed by staging or not - for not to make a genre statement is, of course, to make a statement. 


\section{Tragic Walking}

13 One verb was used repeatedly to describe the way Tamburlaine, Marlowe's outrageous tragic warlord, walked on the stage. He "stalked." So Middleton/Dekker imagines Death personified would resemble "stalking Tamberlaine"; ${ }^{23}$ Hall depicts the man who thinks himself "the Turkish Tamberlaine" and reproduces "The stalking steps of his greate personage"; $;{ }^{24}$ and Middleton describes a man in bed looking up at the ceiling and seeing the "Spindle-shanke Spyders" above "stalking over his head, as if they had bene conning of [rehearsing] Tamburlayne." ${ }^{25}$ These accounts make clear that one aspect that was notably striking about Tamburlaine, as played by the famous actor Edward Alleyn, was his pace. But what was "stalking"? 26

14 The word "stalk", when used of the walk of a hero, may have had its origin in epic poetry. There it signified the gait of a champion - in Heywood's Troia Britanica, for instance, Ajax is described as one who "with huge strides / Stalkes in the field before the best of men." ${ }^{27}$ According to OED, this sense of "stalk" (v1, etymology) originates in the noun meaning "stem, shank or shaft": so the legginess of the walk was, from the start, its central characteristic. In the theatre, when the huge strides were literalised, they often came across as comic. So Ajax has the same walk in Shakespeare's Troilus and Cressida as in Heywood's poem, but is there described as a man so proud that "he stalkes up and downe like a Peacock, a stride and a stand" (TLN 2108-9). As enacted on stage, the stalk was stiff, precious and bird-like, involving, moreover, a pause - "a stand" - at the moment when both legs were widest apart. Ben Jonson also found the walk both laughable and "birdy" (and also used it). He has Truewit in Epicene deplore women who "will stalke i' their gait like an Estrich, and take huge strides": ${ }^{28}$ Ostriches share with peacocks the straddled legs, though their strides are so massive they can cover a full five meters. So usual, indeed so clichéd, was "stalking" for certain kinds of tragic performance that it came to typify acting at its most exaggerated. In Henry Chettle's Tragedy of Hoffman, "Stilt", a fencer named for his stride, "will stalke, and make the earth a stage"; 29 in Jonson's Poetaster the question "What's hee, that stalkes by, there?" receives the answer, "a Player"; 30 while in Thomas Middleton's poem The Ant and the Nightingale, "the Ant began to stalke like a three Quarter sharer" (a player with less than a full share in the acting company). ${ }^{31}$

In Hamlet, the Ghost of Hamlet's father is a "stalker." Accused of "usurp[ing]" the night - unfortunate terminology for a usurped king - the Ghost goes off in a huff, and Bernardo, seeing that the ghost "is offended", gives a running commentary as it "stalkes away" (TLN 63-4). Later Marcellus explains how the Ghost "twice before, and just at this dead houre, / With Martiall stalke, hath [...] gone by our Watch" (TLN 81-2). The Ghost's walk may be the arrogant gait of an old martial war hero, hinting at the Tamburlaine-like prowess with which he fought when alive. If so, the walk is probably staged to differentiate the Ghost from his weaker son who, presumably, does not stride either in so mannered a fashion, or so portentously. Alternatively, given the association of stalking with the big acting of Edward Alleyn, who had played Marlowe's Tamburlaine in $1587 / 88$, this is a dated, old-fashioned walk. In that case, the Ghost has it to show how he belongs to a different, earlier world: it is, after all, not very current to be dead. For whatever reason, the Ghost's walk is called attention to twice, and will have had a particular, metatheatrical effect: in the fiction of Hamlet, Hamlet constantly worries about players who over-act, and specifies "ore-stop[ping]" (TLN 1867), meaning 
"over-stepping", as a feature particularly to be rectified. He is, however, in a play that pointedly calls upon tragic stalking as an aspect of (at least one person's) characterisation. In a telling irony, then, Hamlet rejects and despises the very type of acting that his play exploits.Another verb that related to a special way of tragic walking was "jet." "When the stage of the world was hung in blacke," writes Dekker (a reference to the black tragedy curtains, of course), "they jetted uppe \& downe like proud Tragedians"; 32 in J. W.'s The Valiant Scot, it is "our tragick Muse" itself that now "jets on the stage." ${ }^{33}$ So what was "jetting"? Malvolio in Twelfth Night, dressed in tragedy black and reading a letter he believes to reveal his lady's love for him, is described as "a rare Turkey Cocke" who "jets under his advanc'd plumes" (TLN, 1046-7). In play terms, he is a "tragedy" figure in the wrong genre; in literal terms he has a walk that, when described, appears to be almost identical to "stalking." It was birdy - Piston says of Basilisco in Soliman and Perseda that "He will jet as if it were a Goose on a greene." ${ }^{44}$ And it, too, was used to refer to Tamburlaine's walk: Robert Greene bitterly recalls how critics of his first play, Alphonsus, King of Aragon, said "that I could not make my verses jet upon the stage in tragicall buskins" ("buskins" will be explored later in this essay), "[...] daring God out of heaven with that Atheist Tamburlan". ${ }^{35}$ Perhaps "jet" was "stalk" by another name. It conveyed the same arrogance, so that "proude players" are said to "jett in their silkes"; 36 but the word itself had an advantage over "stalking." "Jet" was, and is, also a term for hard black lignite, hence "jet-black." Those who "jetted" had tragic black in the very name of their gait.Then there was "strutting." It too was associated particularly with the theatre: a ballad admonishes "stage-strutters all"; 37 Anthony Stafford writes of those who "stay, stare, strut, \& look big a long time on the Stage", ${ }^{38}$ the gait of a perfect man is described as "sage and grave, not affected and strouting like a stage-plaier." ${ }^{39}$ Whenever Shakespeare thought about over-acting, "strutting" was the term he used: Hamlet says that bad players have "strutted and bellowed" (Hamlet, TLN 1880); and Macbeth's "poor player" "struts and frets his houre upon the Stage" (Macbeth, TLN 2346). In Troilus, Achilles is compared to "a strutting player, whose conceit / Lies" not in his head, where it should be, but "in his hamstring" (Troilus and Cressida, TLN 614-15). As the strut, too, was compared to the walk of a bird, and to jetting - Vasco in Davenant's Love and Honour accuses his companions of being "content to thrive, to jet / And strut like lustfull Turkeys with your plumes spread" 40 it seems to have been another verbal variant on that straddled walk. It was similar to, and perhaps the same as, "stalking", as is illustrated by Ben Jonson, who, thinking back to Marlowe's Tamburlaine, remembers Alleyn's famous stalk as "strutting": "the Tamerlanes, and Tamer-Chams, of the late Age, which had nothing in them but [...] scenicall strutting. ${ }^{41}$

We have, it seems, three words, stalk, jet, and strut, for three closely connected walks or, perhaps, one walk so tremendous as to generate a range of vocabulary. It was birdlike, stiff, pompous, with a pause at the moment when the stride was as its most wide. Indeed, "stride", too, is a word for a stage walk, as in "Tarquins ravishing $s$ [tr]ides" (Macbeth TLN 635), though that, being the term for the wide-legged moment, is a facet of the other three walks. One picture of the period even shows the stride in action. "The Swan" drawing, a famous illustration of the inside of the Swan Playhouse, copied by Arend Van Buchell from a lost picture by Johannes De Witt, depicts a round theatre on which a scene is being performed. of its three actors, one performs a woman sitting on a bench; one performs a woman standing; and one performs a man approaching the women and/or doing obeisance. With legs wide apart, the man may 
even be using his halberd or stick to steady himself. This is a person frozen forever mid-stride in the process, it seems, of stalking/jetting/strutting (Fig. 2a and 2b).

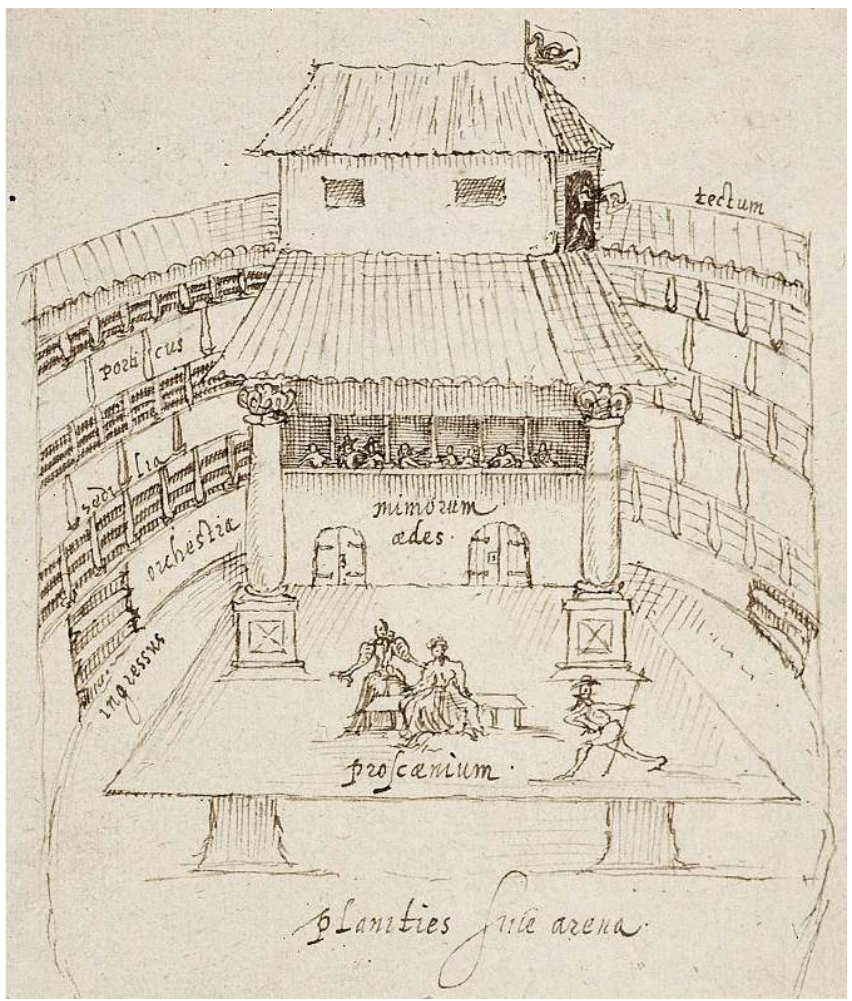

Fig. 2a. Arend van Buchell after Johannes de Witt, The Swan Playhouse (c.1596); University of Utrecht, Ms. 842 .

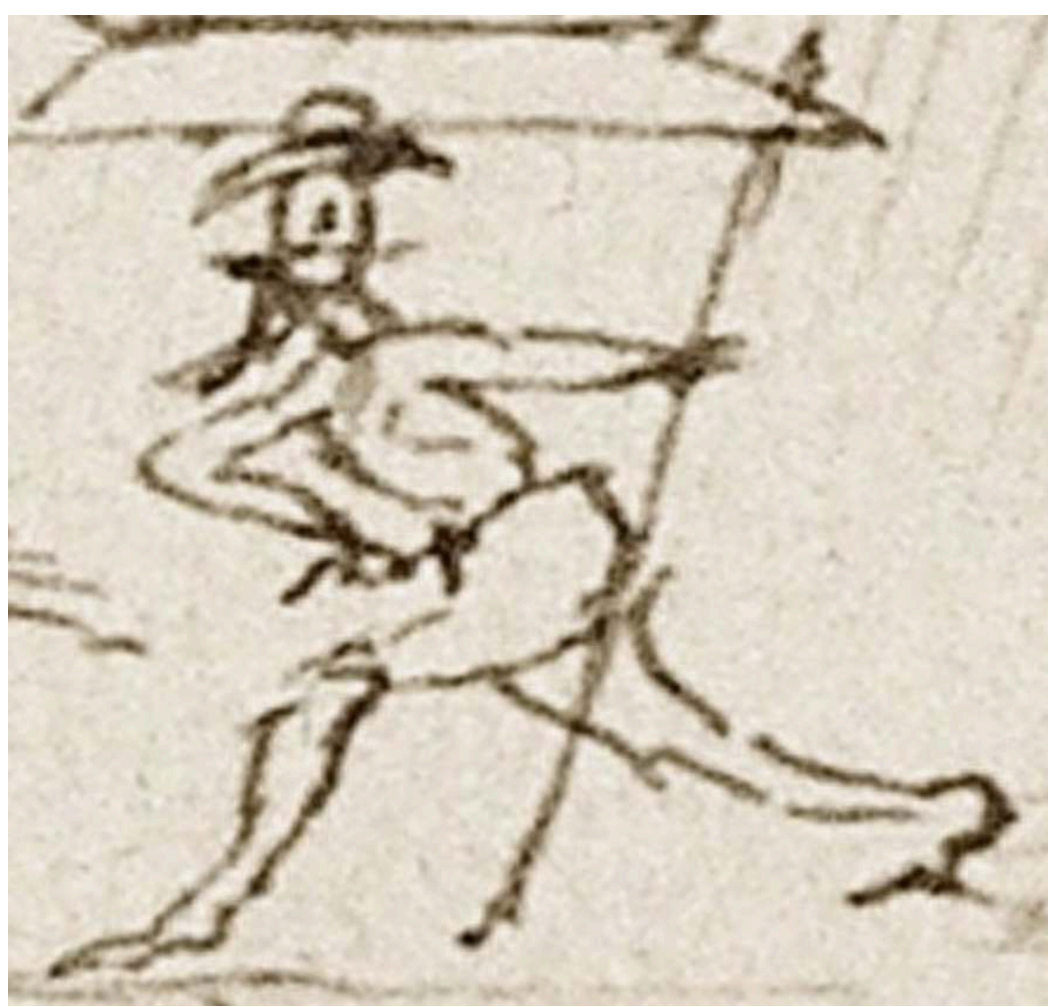

Fig 2b. Close up of "striding" actor. 
So important was that tragic walk that, dated as it was, it made the leap over the interregnum and into the next century. One 1760 account, for instance, shows it to be thriving even at that time:

THEATRIC Monarchs in their tragic Gait

Affect to mark the solemn Pace of State.

One Foot put forward in Position strong,

The other like its Vassal dragg'd along. ${ }^{42}$

The split legs, one leading, and one following, are here parodied, but accepted, as a quintessential aspect of performing tragic royalty.

9 Not to use a tragic walk was also therefore telling. Richard III disparages the notion that he might ever "strut before a wonton ambling Nymph" (TLN 19) - disdaining both strutting and the "ambling" that the imagined women will do in return. But his suggestion that strutting would demean him is probably to "deprecate a performance [...] that he cannot emulate." ${ }^{43}$ Richard III has a limp - he "halts" - and is therefore incapable of maintaining straddled legs. In terms of early modern drama, he cannot walk tragically, and his "deformity" thus denies him not only love but the possibility of being a tragic hero.

Women on stage resembled Richard III insomuch as they, too, were incapable of stalking, for their skirts confined their legs and made wide strides impossible. Thus when Procus and Pinnario enter in women's clothes in The Ghost, Procus is horrified to find the "mincing gate these Coats have taught me": "These she-comrades must needs be nimble-thigh'd, / They practice it in walking so." ${ }^{44}$ Conversely, striding might be possible for women, but only if inappropriately dressed - particularly as men. "When we are both accoutered like young men", says Portia in Merchant of Venice, "ile prove the prettier fellow of the two, [...] and turne two minsing steps / Into a manly stride" (TLN 1791-5). From clothing onwards, then, women were bound to be victims rather than tragic heroes - for even if they adopted the "stalk", as Jonson's women did above, that rendered them horrifyingly masculine, rather than heroic.

Such descriptions suggest, but do not require, special stage footwear to elongate the leg. Stage shoes are indicated by Hamlet when he asks whether his ability at rhyming together "with two Provinciall Roses on my rac'd Shooes" would "get me a Fellowship in a crie of Players" (Hamlet, TLN 2148-50). His pun here on "raz'd" (pinked) but also "raised" (high) footwear, together with its rose decoration, suggests he thinks stage shoes are both vulgarly embellished and high-heeled. ${ }^{45} \mathrm{He}$ may, too, be commenting upon raised stage shoes when he addresses the boy-actor who plays women: "your Ladiship is neerer Heaven then when I saw you last, by the altitude of a Choppine" (TLN 1471-2). A chopine was a high stilt-like clog employed for raising the foot above the dirt of the streets; possibly the boy's height is being measured in chopine terms - doing so would, as ever, draw attention to performance's shoes - or possibly the boy had once needed stage chopines but does so no longer.

The link between actors and high heels had an old precedent. Performers of Greek and Roman "tragedy" had worn the cothurnus or buskin - high heeled boots - giving them what Tom Bishop has called "literal superiority of step and posture"; and performers of Greek and Roman "comedy" had worn the soccus or sock - low slippers - giving them "ease and nimbleness of movement." ${ }^{46}$ These are depicted on the feet of characters etched onto the title page of Ben Jonson's Works: in the middle of the page is a cartouche in which is written the name of the book, the author, and a Horace 
quotation; on either side are "tragoedia" wearing buskins, and "comoedia", wearing socks (in this instance, the embarrassing kind with separate toes). Ben Jonson is certainly using this illustration to claim that his plays have classical antecedents. But is he also claiming that he himself is so far "classical" as to perform his plays in appropriate footwear? Might he imply that others do?

It should be noted here that, in the early modern period, the terms "buskin" and "sock" were regularly used for "tragedy" and "comedy." So when people tried to identify which of Beaumont-and-Fletcher plays had been written by Beaumont, and which Fletcher, they speculated "That One the Sock, th'Other the Buskin claim'd", i.e. that one wrote the comedies and one the tragedies. ${ }^{47}$ Here "sock" and "buskin" are purely metaphorical and reveal little about footwear - except, of course, that genre was directly indicated through them. Often, however, the terms are used ambiguously, so that whether they are to be understood metaphorically or literally is open to question. When the playwright Thomas Heywood observes that poverty is the playwright's lot whether he writes comedy or tragedy, he phrases it in shoe terms:

[...] whether thou the gentle Socke dost weare,

Tickling with pleasure the Spectators eare;

Whether thou in the lofty Buskin rage:

When the long Tragicke Robe doth brush the Stage. ${ }^{48}$

In this description, the poverty is literal, as are the spectators, the stage, and probably the tragic robe. Might the footwear be too? Jonson similarly flirts with the hinterland of literal and metaphorical when he names a range of classical authors to whom dead Shakespeare was superior: Aeschylus, Euripides and various others are summoned to "heare thy Buskin tread, / And shake a Stage"; while "when thy Sockes were on" there are said to be no classical superiors. ${ }^{49}$ Jonson's grudging point is that Shakespeare is good at tragedy, but superlative at comedy - but his boot reference, with its sensitivity to the reverberations of the buskin on the wooden stage, hints at genuine observation from performance.

If boots were sometimes worn for tragedy, as is suggested, too, by the footwear of Titus and Aaron in "The Peacham Drawing" of Titus Andronicus, ${ }^{50}$ then their sound will also have been part of performance. Pye-boord testifies as much in an anonymous play possibly by Middleton, The Puritan [Widow], when he asks "have you never seene a stalking-stamping Player, that will raise a tempest with his toung, and thunder with his heeles?" ${ }^{1}$ indicating that stalking was noisy. Given the well-worn pun "on poetic and histrionic feet" to which David Roberts draws attention, might tragic verse itself sometimes have been stamped out by stalkers, the iambic feet and the literal feet joining together in sound and thud ${ }^{52}$ Whether or not the step matched the verse, the genre of tragedy will have sounded different from the genre of comedy because it thundered where the other shuffled.

The connection between shoe and performance is certainly a lasting one. Tellingly, amongst the archaeological remains of the Rose and Globe playhouses, are "several intact shoes, [and] the remains of two boots or buskins." ${ }^{53}$ These may have belonged to actors or audience, of course (though how either got home without their footwear remains a mystery), but they show how shoe-focussed even a visit to the theatre might be - perhaps because as Kerrigan reminds us, performance, for the nearest spectators, was viewed foot up rather than head down: "The stage [...] was at eye level for the groundlings; they looked straight at legs and feet. ${ }^{{ }^{4} 4}$ And it should not be forgotten 
that one epithet, still current, for acting itself is "treading the boards", showing how performance has long had what Natasha Korda calls "the reliance of [the actor's] art upon footwork and footwear" encoded within it. ${ }^{55}$

This section, then, has suggested that tragic walks were utilised and parodied on the early modern stage; and that they are likely to have required tragic footwear. A play or, as with drapery, a performer, could negotiate with and complicate genre without words, through legs and feet: a stalking performer could elevate, literally, and classicise, notionally, his text. Once again, genre was to the forefront of performance, whether or not the play or actor chose to use the walk or its boots.

\section{Tragic Speech}

When Camden refers to "speaking [...] (as folke say) in a tragicke Key upon the stage" he uses musical terminology to describe the qualities of spoken tragic speech. ${ }^{56} \mathrm{He}$ is joined by a host of writers who choose the general word "tone" for the way actors sound. Collop writes of players who perform with "mimick gesture, and affected tone"; ${ }^{57}$ while in a stage direction to Brome's Court Beggar, Philomel "speaks in a vile tone like a Player." ${ }^{18}$ Both describe tonal speaking as "actorly" and artificial. And, as with tragic walking, tone seems to have been typified by - and perhaps even to have emerged from - Alleyn's Tamburlaine performance. So George Wither, in 1628, writes of poetic rivals and detractors who, when filled with "Selfe praises", are likely to start reading

their new created Verse,

With such a Gesture, and in such a Tone,

As if Great Tamberlaine upon his Throne,

Were utt'ring a majesticall Oration,

To strike his hearers dead with admiration. ${ }^{59}$

Likewise, in Jonson's Poetaster, Tucca says of Crispinus (seemingly a parody of the playwright John Marston) that his writing style is "high, loftie, in a newe stalking straine." ${ }_{0}$ "Stalking straine" not only recalls Tamburlaine's walk, but seems to suggest that it has morphed into or become a way of speaking too. Perhaps there was a deeper connection between the walking and speaking as well: the kind of part that required stalking - or the kind of actor who walked in that fashion - was particularly likely to "tone" his verse.

For early modern definitions of what "tone" actually involved, one needs to look beyond theatre, to works of rhetoric. The Art of Pronounciation, for instance, has a section "Of Tones" explaining how they are brought about, and how they sounded: they were a

lifting up and depressing of the voyce [...] caused by a contraction of the lungs and hollow parts of the body, wherein the ayre is inclosed, sometimes being more speedy sending foorth the ayre through its passages with a swift motion, whereby the sound of the speech is made more forceable to be heard, and sometimes being more slow, \& more weakly pressing forth the ayre, wherby the sound of the speech is somewhat lessened. ${ }^{61}$

This definition also shows why speaking in a tone was practical: it will have made the voice carry and be more audible. Audibility explains, too, why the other speakers who tended to use "tones" were preachers: so much so that when the interregnum began, and theatre was halted for the civil war, a satirical account of the acting profession, the Actors' Remonstrance, promised in the future not to "entertaine any Comedian that shall 
speake his part in a tone, as if hee did it in derision of some of the pious." ${ }^{62}$ Later descriptions focus almost exclusively on the lyrical musicality of using tones. By the $18^{\text {th }}$ century, when actorly speaking had been further divided into "rant, cant, and tone", ${ }^{63}$ Theophilus Cibber praised Barton Booth for the way he sounded on stage:

The Tones of his Voice were all musical [...] no one ever heard a dissonant Note come from him [...] His Voice was raised or sunk, extended or contracted, swelled or softened, rapid or slow, as the Sense and Spirit of the Author or the several Tempers and Emotions of Mind, in different Characters, required. ${ }^{64}$

All these descriptions, of course, demand a particular form of writing that, at its most basic, goes up and down a lot. It is easy to find in parody. In Pyramus and Thisbe, the play-in-a-play in A Midsummer Night's Dream, Bottom as Pyramus is asked to make rapid switches from "high" words (e.g. "arise"), to "low" words (e.g. "dead", "tomb"), in a passage that seems to require "toning" to match sense:

O Piramus arise:

Speake, Speake. Quite dumbe? Dead, dead? A tombe

Must cover thy sweet eyes.

TLN 2117-19

Equally, in the "rugged Pyrrhus" speech spoken by the "tragedians" of Hamlet, a section apparently asks for tonal dexterity, from high ("top"), to low ("Stoopes to his bace"), to lower ("loe"), to lower still ("declining"), where it fixes, stuck like its sword (unless it rises again at "Ayre"):

Then senselesse Illium,

Seeming to feele his blow, with flaming top

Stoopes to his Bace, and with a hideous crash

Takes Prisoner Pyrrhus eare. For loe, his Sword

Which was declining on the Milkie head

Of Reverend Priam, seem'd i'th' Ayre to sticke.

TLN 1515-20

Intriguingly, though, that most simple but effective and "visible" tonal range, high to low, is also found at tragic moments when Shakespeare is not being parodic at all. It is there in Lear, in the description of the high cliff overlooking the deep sea:

There is a cliffe whose high \& bending head

Lookes firmely in the confined deepe.

King Lear, TLN 2258-59

It is there too in Macbeth, when the stars are confronted with the deep nature of Macbeth's wishes:

Starres hide your fires,

Let not Light see my black and deepe desires.

Macbeth, TLN 338-9

And it shapes the contours of the speech in which Mark Antony in Julius Caesar recalls Caesar's high love for Brutus ("Angel”, “Gods"), that has been so bitterly matched by low ingratitude ("vanquish'd", "Base" and, finally, "fell"):

[...] Brutus, as you know, was Caesars Angel.

Judge, O you Gods, how deerely Caesar lov'd him:

This was the most unkindest cut of all.

For when the Noble Caesar saw him stab,

Ingratitude, more strong then Traitors armes,

Quite vanquish'd him: then burst his Mighty heart,

And in his Mantle, muffling up his face,

Even at the Base of Pompeyes Statue 
(Which all the while ran blood) great Caesar fell.

Julius Caesar, TLN 1718-26 Shakespeare, though only the most elemental aspects of it have been touched on here. Up until "naturalism", it was an entrenched way of performing Shakespeare too. It is worth recalling that Joshua Steele, trying to define how Garrick spoke the "To be or not to be" speech two centuries later, in 1775, still found the best way to present it was in musical notation. ${ }^{65}$ Powerful speeches, particularly verse tragic speeches, sounded different from comic ones.

\section{Conclusion}

When Richard Flecknoe put together a poem on "The praises of Burbadge, or of an Excellent Actor", he aimed to identify the skills that made Shakespeare's lead actor, Richard Burbage, so special. He was writing in 1671, however, and can only have seen Burbage perform when a child, for which reason Alfred Harbage discounted his observations. ${ }^{66}$ Yet Flecknoe's comparisons between Burbage's performances and those of Charles Hart ("Such Burbadge was, and such Charles Hart is now") - when he could simply have written a poem on Charles Hart - suggest an attempt to preserve or convey something about Burbage. Moreover, what he says about the nature of the greatness of Burbage's performances, always so difficult to define, focuses on some tellingly particular talents. He has it that in order "on the Stage t'appear with greater grace", Burbage

Weigh'd every word, and measur'd every pace,

And finally did on the Stage appear

Beauty to th'Eye and Musick to the Ear. ${ }^{67}$

According to Flecknoe, Burbage was visually beautiful and aurally magnificent on stage because his "pace" and words were so correct. Suggesting that walking and speaking are at the heart of a great performance, Flecknoe all but says that Burbage (and Charles Hart) was excellent at knowing how and when to stalk and tone.

Those same qualities, bolstering Flecknoe's account, are also extolled in a manuscript elegy surviving in several transcripts. That text, quoted here from the Folger's "On $\mathrm{Mr}$ Richard Burbidg an excellent both player, and painter," laments the actor's demise, and suggests the theatre should "hang all yo[u]r round w[i]th black" - go into mourning, tragedy fashion - because of Burbage's death. Reflecting upon what it was that made Burbage so brilliant, it asks:

how did thy speech become thee? and thy pace

sute $w[i]$ th thy speech, and every action grace

them both alike, while not a word did fall

$w[i]$ thout just weight to ballast it w[i]thall.

Again, then, it was Burbage's pace combined with the way he gave words the correct "weight" that is singled out for praise; once more Burbage is described as having the skills that made for tragic acting. And, given that Shakespeare could only write for what his performers could do, these poems go some way towards suggesting that Burbage's stylish performances brought about Shakespeare's tragedies.

What, then, to conclude about genre and staging more broadly? As genre is sometimes named on play title pages and sometimes not, possibly reflecting playbills of the period, 
${ }^{68}$ it seems to have been of more importance to some texts than others (though there are, too, plays like Shakespeare's Richard III, that change designation, from tragedy to history, when reprinted: perhaps it was sometimes differently important). For tragedy, what can be said is that the genre was never understood to be solely a Latin category: it was always potentially a lively and complex aspect of performance, though we cannot know when or how. And, as the burden of genre might belong to the stage, a character, a moment, a speech, it could manifest as a mood or state of mind - particularly when in curtains, for instance - or as a "character" in that it could enter, exit, develop or change, particularly when it was on footwear or in a speech. As readers and watchers, then, we need to be alert to the moments when genre might have been placed in staging, boots or sound, and consider what that implies for the look of the play and its relationship to the tragic form. Finally, as shown in this article, genre was a site of contention: exploiting it and parodying it might both happen in the same play. Genre, always a possible aspect of production, was always there in potentia, and curtains, feet and speech are three of the key places where, in tragic form, it might be located.

\section{NOTES}

1. Grateful thanks to my two anonymous reviewers: their comments and suggestions have made this a better piece. Edward Phillips, The New World of English Words, 1658, sig. 2P3r.

2. John Florio, Queen Anna's New World of Words, 1611, sig. K2r.

3. First Folio quotations are taken throughout from the facsimile prepared by Charlton Hinman, Mr. William Shakespeares Comedies, Histories, \& Tragedies [The Norton Facsimile] New York, Norton, 1968, using the through-line-numbers (TLN) of that edition.

4. Ben Jonson, The Workes, 2 vols, 1616, vol. 1, sig. F6v; sig. 203v.

5. An earlier version of these issues is explored in Tiffany Stern, "Tragedy and Performance", The Oxford Handbook of Shakespearean Tragedy ed. Michael Neill and David Schalkwyk, Oxford, Oxford University Press, 2016, p. 489-504.

6. Richard Verstegan (alias Richard Rowlands), "Visions of the Worlds Instabilitie", in Odes in Imitation of the Seaven Penitential Psalmes, 1601, p. 109.

7. A Warning for Faire Women, 1599, sig. A3r.

8. The moment when a play starts, as opposed to when a playtext starts, is discussed in Tiffany Stern, "Before the Beginning; After the End: When did Plays Start and Stop?" in Shakespeare and Textual Studies ed. M. J. Kidnie and Sonia Massai, Cambridge, CUP, 2015, p. 358-374.

9. Thomas Dekker, North-ward Hoe, 1607, sig. E3r.

10. William Browne, Britannia's pastorals. The first booke, 1625, p. 117.

11. For more examples, see Mariko Ichikawa, “'The Stage is Hung with Blacke': On the Use of Black curtains from Tragedies in the Early Modern Period", Theatre Notebook, 68, 2014, 153-188; and Stern, "Tragedy and Performance".

12. John Marston, The insatiate countesse, 1613, sig. H2r. 
13. John Taylor, The Water-Cormorant his Complaint, 1622, sig. A4r.

14. Jasper Mayne, A late printed sermon against false prophets, 1647, sig. F2r.

15. Jonson, Cynthias Revels in The Workes, 2 vols, 1616, vol. 1, sig. Q2r.

16. Ichikawa, art.cit., p. 158.

17. Nathaniel Richards' Messallina, 1640, sig. A8v.

18. Nathaniel Richards' Messallina, 1640, sig. B1v. The plate was by Thomas Rawlins, a playwright too; see John H. Astington, “The 'Messalina' Stage and Salisbury Court Plays", Theatre Journal, 43, 1991, 141-156, p. 142.

19. Ichikawa, art. cit., p. 175-77. She cites Philip Massinger's City Madam for which an "arras" was hung for musicians - though this more obviously illustrates adding a curtain than replacing one. She also speculates that black curtains were changed for the wedding masque in Insatiate Countess and to show new locations in Doctor Faustus. Both are possible: but as both are guesswork, it is equally likely that these upbeat scenes were framed in tragic black - indeed, given the direction of both plays, foreboding curtains might make better sense.

20. Michael Neill, Issues of Death: Mortality and Identify in English Renaissance Tragedy, Oxford, Clarendon Press, 1997, p. 282.

21. Eldred Jones, Othello's Countrymen: the African in English Renaissance Drama, London, Oxford University Press, 1965, p. 120, gives accounts from the 1540s and 50s that show black velvet was a standard material for blackening actors' appendages; that Othello will have used a tempura eggbased makeup for his actual face is explored by Richard Blunt in "The Evolution of Blackface Cosmetics on the Early Modern Stage" in The Materiality of Color, ed. Andrea Freeser, Maureen Daly Goggin, and Beth Fowkes Tobin, 2012, London, Routledge, 2016, p. 226.

22. Patrick Sawyer, in “'Traditional' theatre lighting and stage design discriminates against black and Asian actors, warns Shakespeare's Globe”, The Telegraph, 12 August, 2018, quotes Farah Karim-Cooper as saying "Using the same lighting and stage design as you do for white actors puts actors of colour at a disadvantage. There is a danger with traditionally dark, tragic, stage settings, that actors of colour merge into the background."

23. Thomas Dekker, The Wonderfull Yeare, 1603, sig. D1r.

24. Joseph Hall, “Satire III”, Virgidemiarum, 1598, p. 7.

25. Thomas Middleton, The Blacke Booke, 1604, sig. D1r.

26. Edward Alleyn's stalking is explored in Andrew J. Gurr, "Who Strutted and Bellowed", Shakespeare Survey, 16, 1963, p. 95-102.

27. Thomas Heywood, Troia Britanica, 1609, p. 324. My thanks to Charlotte Coffin for alerting me to this quotation and for email exchanges about "stalking" in Heywood's epic poetry and on stage.

28. Jonson, Epicene in Workes, vol. 1, sig. 3b1v.

29. Henry Chettle, The tragedy of Hoffman, 1631, sig. C4v.

30. Ben Jonson, Poetaster, 1602, sig. F1r.

31. Thomas Middleton, The ant, and the nightingale: or Father Hubburds tales, 1604, sig. B4r.

32. Thomas Dekker, Lanthorne and Candle-light, 1609, sig. L1v.

33. J. W., The valiant Scot, 1637, sig. E1r.

34. The tragedye of Solyman and Perseda, 1592, sig. B3r.

35. Robert Greene, Perimedes the black-smith, 1588, sig. A3r.

36. Letter from a soldier to Sir Francis Walsingham, Jan 25 1586/7, quoted in E. K.

Chambers, The Elizabethan Stage, 4 vols, Oxford, Clarendon Press, 1923, vol. 4, p. 304. 
37. "A Sonnett upon the Pittifull Burneing of the Globe Play House in London", reproduced in Peter Beal, "The Burning of the Globe", Times Literary Supplement, 20 Jun 1986, p. 689-690.

38. Anthony Stafford, Honour and vertue, triumphing over the grave, 1640, sig. M3v.

39. Thomas Walkington, The Optick Glasse of Humors, 1607, sig. 80v.

40. William Davenant, Love and honour, 1649, sig. D1v.

41. Ben Jonson, Timber in Workes, 1641, vol. 2, sig. N4v.

42. Robert Lloyd, The Actor, 1760, 6. For more on the Restoration tragic strut, see Alan S. Downer, "Nature to Advantage Dressed: Eighteenth Century Acting", PMLA, 58, 1943, 1002-1037, p. 1009-10.

43. John Kerrigan, "Shakespeare afoot" in Shakespeare's Originality, Oxford, OUP, 2018, p. 44.

44. Anon, The Ghost or The woman wears the breeches, 1653, sig. E1r. For more on footwork as an indicator of genre, see Natasha Korda, "How to Do Things with Shoes" in Shakespeare and Costume ed. Patricia Lennox and Bella Mirabella, London, Bloomsbury, 2015, p. 90.

45. The pun is elaborated in Natasha Korda, "Understanding Shakespeare's Shoes", Shakespeare's Things ed. Brett Gamboa and Lawrence Switzky, London, Routledge, 2019, p. 42.

46. Tom Bishop, "Boot and Shtick", Shakespeare Studies, 43, 2015, 35-49, p. 37.

47. J. Berkenhead, “On the happy Collection of Master FLETCHER'S Works, never before PRINTED," in Francis Beaumont and John Fletcher, Comedies and tragedies, 1647, sig. e1v.

48. Thomas Heywood, The hierarchie of the blessed angells, 1635, sig. S2r.

49. Ben Jonson, "To the memory of my beloued, The AVTHOR MR. VVILLIAM

SHAKESPEARE: AND what he hath left vs", in William Shakespeare, Mr. VVilliam

Shakespeares comedies, histories, \& tragedies, 1623, sig. A4r.

50. Henry Peacham, "Drawing of Titus Andronicus", c. 1595, Harley Papers, Library of Longleat House. The image is widely reproduced on the internet.

51. The Puritaine, 1607, sig. F1v.

52. David Roberts, "Ravishing Strides: Signs of the Peripatetic in Early Modern Performance", New Theatre Quarterly, 17, 2001, 18-30, p. 20.

53. Natasha Korda, “Understanding Shakespeare's Shoes" in Shakespeare's Things, ed. Brett Gamboa and Lawrence Switzky, London, Routledge, 2019, p. 42.

54. John Kerrigan, "Shakespeare afoot" in Shakespeare's Originality, Oxford, OUP, 2018, p. 45.

55. Natasha Korda, "How to Do Things with Shoes" in Shakespeare and Costume, ed. Patricia Lennox and Bella Mirabella, London, Bloomsbury 2015, p. 86.

56. William Camden, Britain, 1637, p. 78r.

57. John Collop, Poesis Rediviva, 1656, p. 36.

58. Richard Brome, The Court Begger, 1653, sig. S3r-S3v.

59. George Wither, Britain's remembrancer, 1628, p. 205.

60. Ben Jonson, Poetaster, 1602, sig. F1v.

61. Robert Robinson, The art of pronuntiation, 1617, sig. C3r-v.

62. The Actors remonstrance or complaint for the silencing of their profession, 1643, p. 8.

63. Quoted in John Harold Wilson, "Rant, Cant, and Tone on the Restoration Stage", Studies in Philology, 52, 1955, p. 592-598. 
64. Theophilus Cibber, The Lives and Characters of the most Eminent Actors and Actresses of Great Britain and Ireland, 1753, p. 44.

65. Joshua Steele, An Essay Towards Establishing the Melody and Measure of Speech, 1775, p. 14.

66. Alfred Harbage, “Elizabethan Acting”, PMLA, 54, 1939, 685-708, p. 695.

67. Richard Flecknoe, Epigrams, 1671, p. 56-57.

68. See Tiffany Stern, Documents of Performance in Early Modern England, Cambridge, CUP, 2009, chapter 2.

\section{ABSTRACTS}

Tragedy is a category of play. But was it, in Shakespeare's time, a method of acting too? This article explores tragic "black" curtains; the tragic walk (stalking, jetting, strutting, striding) and its accompanying footwear; and tragic speech. It argues that tragedy was often conveyed beyond, beside or without words, and shows how crucial staging was to a play's genre - and hence its meaning.

La tragédie est une catégorie de pièces, mais était-ce aussi, au temps de Shakespeare, une manière de jouer? Cet article s'intéresse aux rideaux « noirs » tragiques; à la manière tragique de marcher (d'un air arrogant, pompeux, important, à grandes enjambées) et d'être chaussé, et à la manière tragique de parler. Il montre que le tragique se transmet par-delà les mots, par rapport à eux ou sans eux et que la mise en scène est d'une importance cruciale pour le genre - et donc pour le sens - de la pièce.

\section{INDEX}

Keywords: Genre, tragedy, staging, curtains, stalking, jetting, strutting, striding, toning, Shakespeare William, Jonson Ben, Marlowe Christopher, Burbage Richard

Mots-clés: Genre littéraire, tragédie, mise en scène, rideaux, démarche arrogante, démarche pompeuse, se pavaner, marcher à grands pas, Shakespeare William, Jonson Ben, Marlowe Christopher, Burbage Richard

\section{AUTHOR}

\section{TIFFANY STERN}

Shakespeare Institute / University of Birmingham 